\title{
万能細胞からの赤血球前駆細胞株の樹立 献血に頼らない輸血用赤血球供給体制を目指して
}

これまで，ケガに伴う失血をはじめ，輸血を必要とす る手術や治療には, 献血によって集められた輸血用赤血 球や血液製剂が使用され，多くの人命が救われてきた. しかし近年になって, 少子高年齢化に伴う献血者の減少 に加え，検査体制の不備や技術不足のため, 輸血が肝炎 ウイルスや HIV などの感染をひき起こす原因の一つに なっていることが大きな社会問題となっている．特に感 染症に関しては，検査体制を確立しても「感染初期の検 査陰性」や「未知なる感染症」などのリスクを完全に取 り除くことは不可能であり, さらに検査項目が増えるこ とで費用がかさむなどの問題むある。このことから安全 な輸血用赤血球および血液製剤を人工的に大量生産する 技術の開発が期待されている.

一方，万能細胞と呼ばれる ES (Embryonic Stem) 細 胞や iPS (induced Pluripotent Stem) 細胞から移植可能 な臓器を作製するという再生医療研究が脚光を浴びてい る.これまでに, 万能細胞を用いた多くの研究成果 ${ }^{(1 \sim 3)}$ から，赤血球を含む血液系細胞も誘導可能であることが 明らかとなっている，そこで筆者らは，万能細胞から輸 血用赤血球を大量生産できないかと考え, まずカニクイ ザル ES 細胞から効率良く血液系細胞を分化誘導する技 術の開発に取り組んだ. その結果, 全血球系細胞（成熟 白血球, 成熟赤血球, 血小板前駆細胞など）の誘導に成
功し, さらに長期（約 6 力月）にわたって血液細胞を産 生することができる培養系を開発した(4). しかし，誘導 するまでに 2 3 週間程度の期間が必要であること, 赤 血球のみを選択的に誘導することは困難であったことな どから，大量生産は難しいと思われた。

この問題は, 赤血球のみに分化し，さらに増殖可能で ある赤血球前駆細胞株を樹立することでクリアできるの ではないか（図 1)、筆者らは，カニクイザル ES 細胞を 用いて確立した分化誘導培養系を応用して，マウス ES 細胞から血液系細胞を分化誘導し, 長期継代培養するこ とで細胞株の樹立を試みた。 その結果，マウス $\mathrm{ES}$ 細胞 株 8 株から， 5 種類の血液前駆細胞株を樹立することが できた.このうち 2 種類は肥満細胞系, 他の 3 種類は赤 血球系の細胞株（赤血球前駆細胞株, MEDEP : Mouse Embryonic stem cell-Derived Erythroid Progenitor) であることが判明した。

3 種類の赤血球前駆細胞株は，すべて試験管の中で分 化能力をもち，分化後にはへモグロビンを合成して細胞 が赤くなり，さらに脱核赤血球（核のない赤血球）にま で分化することが明らかとなった（図 2). 次に，樹立し た赤血球前駆細胞株がマウス生体内でも分化でき，脱核 赤血球を産生する能力があるか否かを調べるため, 急性 貧血を誘発したマウスへ赤血球前駆細胞株を移植してみ

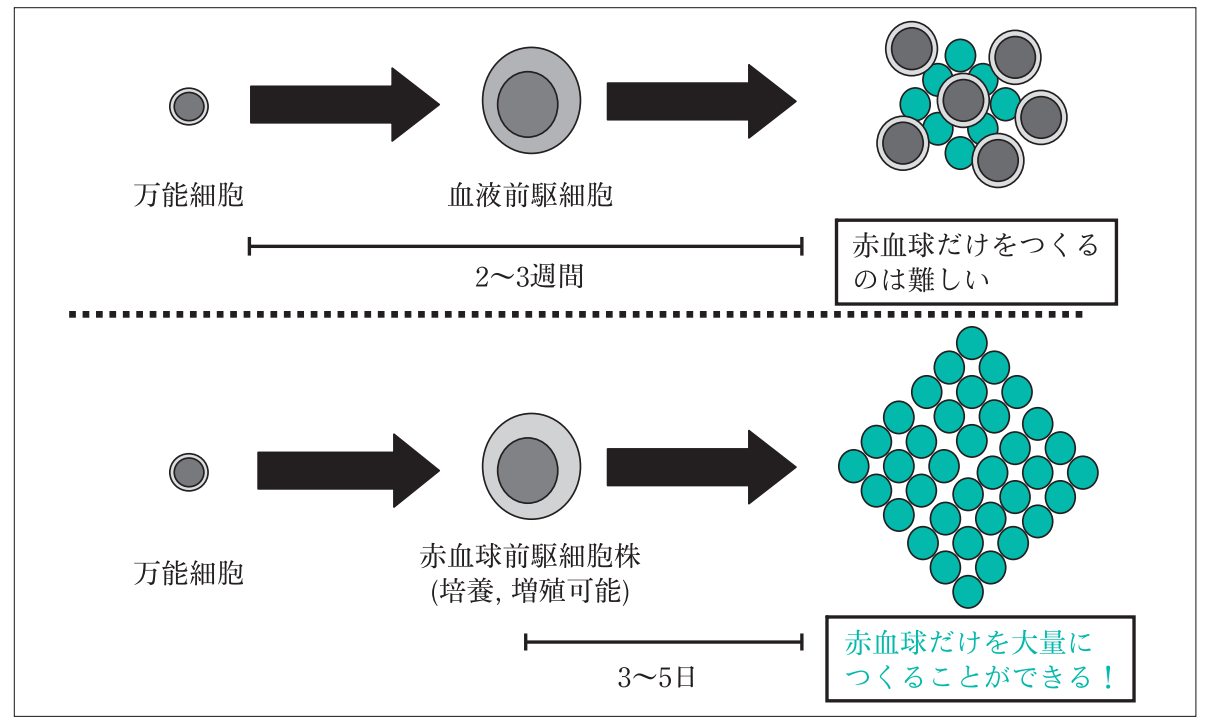

図 1 - 赤血球前駆細胞株樹立のメ リット

赤血球前駆細胞株を樹立することに より，赤血球のみを短期間に，大量 に，そして無限に産生することがで きる可能性がある. また品質管理の 徹底により輸血による感染症を防ぐ ことが可能となる。 


\section{今日の話題}

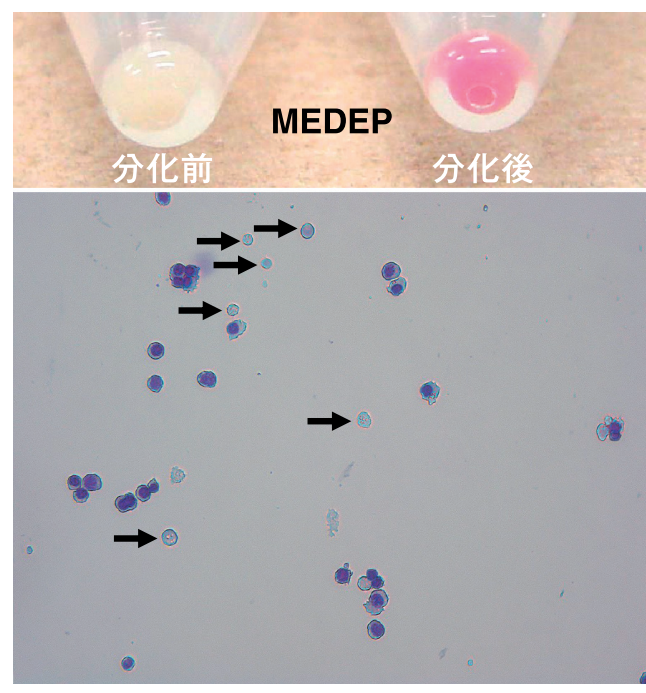

図 2 - 赤血球前駆細胞 (MEDEP)

赤血球前駆細胞 (MEDEP) は分化せずに増殖している間は赤く ないが, 分化させることにより赤くなり (写真上), 脱核赤血球 になる (写真下，矢印).

たところ，赤血球前駆細胞株を移植したマウス群では， 比較対照となる細胞（肥満細胞系細胞株）を移植した群 と比べて有意に貧血が改善した，さらに，より強度な貧 血を誘導したマウスでは, 赤血球前駆細胞株を移植した マウス群では 8 匹中 7 匹が生存していたが，比較対照群 では 8 匹中 1 匹しか生存できなかった。したがって，移 植した赤血球前駆細胞株からできた赤血球が生体内で機 能していることが示唆された. また, 赤血球前駆細胞株 を移植したマウスでは, 腫瘍形成はまったく認められな かった か. $^{(5)}$

このように，マウス $\mathrm{ES}$ 細胞から機能的脱核赤血球を 産生しうる赤血球前駆細胞株の樹立に成功したことは, ヒト ES 細胞やヒト iPS 細胞からも同様にヒト赤血球前 駆細胞株を樹立できる可能性に加え，生体外において赤 血球を工業的に大量生産できる可能性も示唆するもので ある．万能細胞から誘導した細胞を用いて移植を行なう 場合には組織適合性が問題となる，移植後の拒絶を回避 するには，患者さん自身の iPS 細胞または核移植 ES 細 胞，または患者さんに適合する組織適合抗原をむった万 能細胞を用いて, 目的の細胞を誘導する必要性がある. これに対し, 赤血球輸血は通常の臟器移植とは異なり, 移植（輸血）の際に問題になるのは $\mathrm{ABO}$ 式および Rh 式の血液型のみである。理論的には， $\mathrm{O}$ 型 $\mathrm{Rh}(-)$ の七 卜赤血球前駆細胞株を樹立し, 脱核赤血球を大量生産す
ることができれば，特殊なケースを除いて，すべての患 者に輸血が可能になる，さらに，万能細胞は生体に移植 することで腫瘍を形成する可能性をむった細胞であるこ とから, 万能細胞由来細胞の移植に際してはこの問題を クリアする必要があるが，赤血球は核をもたない細胞で あるため, 腫瘍形成の危険性はほぼゼロである。つまり, 万能細胞由来の赤血球の臨床への応用は他の組織に比べ てハードルが低い，また，こうして生産した赤血球をあ らかじめ検査し，品質管理を万全にすれば，感染症のリ スクを回避するとともに検查費用の削減にもつながる可 能性もあると考えられる.

現在筆者らは，ヒト ES 細胞やヒト iPS 細胞からの七 卜赤血球前駆細胞株の樹立を目指して研究を進めてい る。これまでに，臍帯血中に存在する血液幹細胞から効 率良く脱核赤血球を生産する分化誘導技術を開発してお

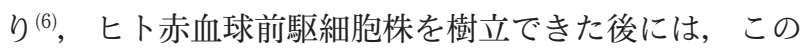
分化誘導技術を応用して, 輸血可能な脱核赤血球を効率 良く生産する技術を開発することを目指している，将来 的には，献血に頼らない輸血用赤血球供給システムを確 立したいと考えている。

1) T. Nakano, H. Kodama \& T. Honjo : Science, 265, 1098 (1994).

2) D. S. Kaufman, E. T. Hanson, R. L. Lewis, R. Auerbach \& J. A. Thomson : Proc. Natl. Acad. Sci. USA, 98, 10716 (2001).

3) J. Hanna et al. : Science, 318, 1920 (2007).

4) T. Hiroyama, K. Miharada, N. Aoki, T. Fujioka, K. Sudo, I. Danjo, T. Nagasawa \& Y. Nakamura : Exp. Hematol., 34, 760 (2006).

5) T. Hiroyama, K. Miharada, K. Sudo, I. Danjo, N. Aoki \& Y. Nakamura: PLoS ONE, 3, e1544 (2008).

6) K. Miharada, T. Hiroyama, K. Sudo, T. Nagasawa \& Y. Nakamura: Nature Biotechnol., 24, 1255 (2006).

（寛山 隆, 中村幸夫, 理化学研究所バイオリソースセ ンター) 